\title{
OPTIMASI WAKTU REAKSI PEMBENTUKAN KOMPLEKS INDOFENOL BIRU STABIL PADA UJI N-AMONIA AIR LIMBAH INDUSTRI PENYAMAKAN KULIT DENGAN METODE FENAT
}

\section{OPTIMIZATION OF THE REACTION TIME ON THE FORMATION OF STABLE INDOPHENOL BLUE COMPLEX FOR N-AMMONIA ANALYSIS IN THE TANNERY WASTEWATER USING PHENATE METHOD}

\author{
Rihastiwi Setiya Murti*, Christiana Maria Herry Purwanti \\ Balai Besar Kulit Karet, dan Plastik Yogyakarta \\ *E-mail: rihastiwi-sm@kemenperin.go.id
}

Diterima: 9 Maret 2014 Direvisi: 13 Mei $2014 \quad$ Disetujui: 20 Mei 2014

\begin{abstract}
Optimization of the reaction time on the formation of indofenol blue complex for N-Ammonia analysis in the tannery wastewater using phenate method has been carried out. The aim of the study was to determine the optimum time for complex formation of indophenol blue. Variations of reaction time were $1 ; 2 ; 2,5 ; 3$; and 21 hours. Accuracy and precision were evaluated to determine the feasibility of developing the method. Analysis of N-Ammonia was done by using a spectrophotometry at a wavelength of $630 \mathrm{~nm}$. Optimum reaction time on the formation of indofenol blue complex for ammonia analysis in the tannery wastewater was achieved at a minimum time of 2 hours at the temperature test of $25^{\circ} \mathrm{C}$. The accuracy and relative percent different were $90-97 \%$ and $<5 \%$ respectively, met the SNI-6989.30-2005 so that the method was feasible to be developed and used in the laboratory.
\end{abstract}

Keywords: ammonia, tannery wastewater, phenate method

\begin{abstract}
ABSTRAK
Telah dilakukan penelitian optimasi waktu reaksi pembentukan kompleks indofenol biru pada pengujian N-Amonia dalam limbah cair industri penyamakan kulit menggunakan metode Fenat. Penelitian ini bertujuan untuk menentukan waktu optimum untuk pembentukan kompleks indofenol biru. Variasi yang dilakukan adalah waktu reaksi yaitu 1 jam, 2 jam, 2,5 jam, 3 jam, dan 21 jam. Akurasi dan presisi juga dievaluasi untuk mengetahui kelayakan pengembangan metode. Analisis $\mathrm{N}$-Amonia dilakukan dengan menggunakan spektrofotometri pada panjang gelombang $630 \mathrm{~nm}$. Waktu reaksi optimum pembentukan kompleks indofenol biru pada pengujian amonia dalam limbah cair industri penyamakan kulit dicapai pada waktu minimal 2 jam pada suhu uji $25^{\circ} \mathrm{C}$. Nilai akurasi sebesar 90-97\% dan relative percent different $<5 \%$ memenuhi SNI-6989.30-2005 sehingga metode ini layak untuk dikembangkan dan digunakan di laboratorium.
\end{abstract}

Kata kunci: amonia, air limbah penyamakan kulit, metode fenat

\section{PENDAHULUAN}

Amonia adalah suatu senyawa nitrogen yang banyak digunakan untuk produksi berbagai komoditi seperti pupuk, obat-obatan, dan lain-lain. Di alam amonia berasal dari air buangan industri (Ashrafizadeh and Khorasani, 2010) dan biodegradasi senyawa organik secara mikrobiologis (Li et al., 2013). Salah satu industri penghasil amonia adalah industri penyamakan kulit. Industri penyamakan kulit dalam operasinya menghasilkan limbah cair, padat dan gas. Limbah cair merupakan limbah yang paling banyak dibuang oleh industri penyamakan kulit. Menurut Gubernur Kepala 
Daerah Istimewa Yogyakarta (2010), N-amonia merupakan parameter yang wajib diuji untuk monitoring tingkat pencemaran limbah cair industri penyamakan kulit. Hal ini karena penyamakan kulit menggunakan amonium sulfat $(\mathrm{NH} 4)_{2} \mathrm{SO}_{4}$ yaitu pada proses deliming (proses pembuangan kapur). Amonia adalah gas berbau busuk dan mudah menguap, serta jika di atas ambang batas dapat menimbulkan dampak berbahaya bagi tubuh jika terpapar atau terhirup. Terpapar $\mathrm{N}$-amonia dalam konsentrasi tinggi dapat menyebabkan kulit, mulut, kerongkongan dan mata terasa terbakar, dan pada konsentrasi sangat tinggi dapat menyebabkan kematian. Mengingat tingkat toksisitas amonia relatif tinggi, maka teknik penentuan kadar amonia dalam sampel uji harus benar-benar diperhatikan. Toksisitas amonia LC50 mempunyai nilai yang sangat rendah hampir mendekati ambang batas yang diijinkan dan mempunyai dampak pada reaksi biokimia (Maas et al., 2012).

Telah banyak metode uji digunakan untuk penentuan kadar amonia dalam air limbah, diantaranya metode spektrometri, ion kromatografi, voltametri, potensiometri, dan distilasi-titrasi (Tzollas et al., 2010; Ya'nan et al., 2009; Qingjun, 2009). Metode uji yang secara luas digunakan untuk penentuan amonia dalam air alami dan sampel-sampel yang lain adalah metode uji yang berdasarkan pada pembentukan senyawa indofenol biru (metode fenat) atau Berthelot Reaction (Duka and Cullaj, 2010). Menurut APHA-AWWA-WEF (1998), dengan metode SM-4500-1998, penentuan amonia salah satunya dilakukan dengan metode Fenat melalui reaksi pembentukan kompleks indofenol biru dengan waktu stabilitas kompleks (waktu reaksi) indofenol biru antara 1-24 jam. Pada penentuan amonia dalam limbah cair industri penyamakan kulit dengan waktu reaksi 1 jam pada suhu ruang dengan metode fenat, kompleks indofenol biru yang terbentuk belum stabil. Hal ini terlihat dari pembacaan absorbansi yang terus naik atau berubah. Fenomena ini diduga karena komponen air limbah penyamakan kulit sangat kompleks, baik senyawa organik, anorganik maupun logam-logam berat yang dapat mengganggu reaksi pembentukan kompleks indofenol biru. Berdasarkan alasan tersebut, dilakukan penelitian tentang optimasi waktu kestabilan kompleks indofenol biru pada pengujian $\mathrm{N}$-amonia dalam limbah cair industri penyamakan kulit menggunakan metode Fenat. Waktu reaksi yang optimum perlu ditentukan karena waktu reaksi pembentukan kompleks indofenol biru sangat tergantung pada kondisi reaksi yang diterapkan di tiap negara (Park, et al. 2009). Penelitian tentang metode uji amonia dalam limbah cair di antaranya tentang akurasi pengujian amonia dengan berbagai metode (Souza, 2013) dan pengembangan analisis amonia dengan metode Fenat ((Duka and Cullaj, 2010; Tzollas et al., 2010). Analisa kuantitatif untuk amonia dengan metode yang lain juga telah banyak dilakukan seperti penentuan nitrogen amonia pada konsentrasi rendah pada limbah cair (Sattayatewa et al., 2011), analisa kuantitatif N-Amonia pada sedimen wetland (Wang et al., 2011), pengujian amonia pada kualitas air minum (Jia, 2010) dan perubahan amonia pada nitrifikasi lumpur aktif (Sonthipand and Limpiyakorn, 2010).

Pendekatan yang dilakukan dalam penelitian ini adalah dengan variasi waktu pembentukan kompleks indofenol biru yang stabil, dan dilanjutkan penentuan akurasi dan presisi metode fenat dengan menggunakan waktu optimum yang diperoleh. Dengan hasil penelitian ini diharapkan dapat dihasilkan suatu metode uji penentuan amonia dalam air limbah penyamakan kulit yang cepat (diharapkan tidak sampai 24 jam), akurat dan teliti serta dapat dijadikan acuan dalam pengujian di laboratorium. Tujuan penelitian ini adalah menentukan waktu optimum untuk pembentukan kompleks indofenol biru dalam pengujian limbah cair industri penyamakan kulit agar didapatkan suatu metode yang akurat dan layak dikembangkan di laboratorium.

\section{BAHAN DAN METODE Bahan Penelitian}

Bahan-bahan penelitian adalah amonium klorida (Merck, pa.), fenol (Merck, pa.), etil alkohol (Merck, pa.), natrium nitroprussida (Merck, pa.), trinatrium sitrat (Merck, pa.), natrium hidroksida (Merck, pa.), natrium hipoklorit (Merck, pa.), air limbah penyamakan kulit dari perusahaan kulit di Yogyakarta, akuades, dan kertas saring Whatman 41. 


\section{Peralatan Penelitian}

Alat-alat yang digunakan adalah spektrofotometer UV-VIS (Shimadzu UV 1601 PC) dan shaker.

\section{Metode Penelitian}

Membuat kurva kalibrasi untuk uji N-amonia

Spektrofotometer UV-VIS dioptimalkan sesuai metode uji $\mathrm{N}$-amonia. Dibuat kurva kalibrasi dengan larutan standar yang mengandung kadar amonia berturut-turut 0 ; 0,$1 ; 0,2 ; 0,3 ;$ dan 0,5 mg N/1. Ditambahkan $1 \mathrm{ml}$ fenol dan dihomogenkan. Selanjutnya larutan standar ditambah $1 \mathrm{ml}$ natrium nitroprusid dan dihomogenkan. Setelah itu ditambah 2,5 ml reaktan oksida, dihomogenkan. Erlenmeyer ditutup dan dibiarkan selama berturut-turut 1; 2; 2,5; 3; dan 21 jam. Dimasukkan ke dalam kuvet spektrofotometer, dibaca serapannya pada panjang gelombang $(\lambda) 630 \mathrm{~nm}$. Uji dilakukan pada suhu ruang $\left( \pm 25^{\circ} \mathrm{C}\right)$. Selanjutnya dibuat kurva kalibrasi waktu pembentukan kompleks stabil pengompleksan dan ditentukan persamaan regresinya dan dibandingkan dengan kriteria keberterimaan metode

\section{Menentukan akurasi (Recovery standard)}

Ke dalam 10 sampel limbah cair penyamakan kulit ditambahkan sejumlah standar amonia dengan konsentrasi tertentu (spike matriks), kemudian diuji kadar N-Amonianya. Dihitung \% Recoverynya dengan persamaan (1) berikut (Achmad et al., 2010):

$$
\% \text { Recovery }=\frac{\left(\mathrm{C}_{1}+\mathrm{C}_{2}\right)-\left(\mathrm{C}_{1}\right)}{\mathrm{C}_{2}} \times 100 \%
$$

$\mathrm{C}_{1}$ adalah konsentrasi limbah sebelum ditambah larutan standar, $\left(\mathrm{C}_{1}+\mathrm{C}_{2}\right)$ adalah konsentrasi limbah ditambah larutan standar, dan $\mathrm{C}_{2}$ adalah konsentrasi larutan standar.

\section{Menentukan presisi metode}

Disiapkan 5 sampel air limbah cair industri penyamakan kulit dan dihomogenkan. Sampel diuji kadar $\mathrm{N}$-amonianya masing-masing dengan dua ulangan. Nilai Relative Percent Difference (RPD) dihitung dengan persamaan (2) sebagai berikut (Achmad et al., 2010):

$$
\% \mathrm{RPD}=\frac{\left(\mathrm{X}_{1}-\mathrm{X}_{2}\right)}{\left(\mathrm{X}_{1}+\mathrm{X}_{2}\right) / 2} \times 100 \%
$$

$\mathrm{X}_{1}$ adalah pengujian ke-1 dan $\mathrm{X}_{2}$ adalah pengujian ke-2.

\section{HASIL DAN PEMBAHASAN \\ Pembuatan Kurva Standar untuk Pengujian N-amonia}

Sebelum dilakukan pengujian kadar N-Amonia dalam limbah cair industri penyamakan kulit, hal pertama yang dilakukan adalah membuat kurva kalibrasi. Dalam pembuatan kurva kalibrasi dilakukan variasi waktu kestabilan pembentukan kompleks indofenol biru dengan metode fenat. Kurva kalibrasi yang didapat dalam penelitian ini disajikan dalam Gambar 1.

Gambar 1 menunjukkan bahwa, pembuatan kurva standar dengan waktu pembentukan kompleks stabil selama 60 menit belum pada kondisi optimum. Kurva standar terlihat bengkok dibandingkan kurva dengan variasi waktu 90 menit sampai 21 jam yang tidak berbeda nyata. Konsentrasi amonium $\left(\mathrm{NH}_{4}^{+}\right)$ditentukan dengan Spektrofotometer UV-Vis pada $\lambda=630$ nm dengan metode fenat (APHA-AWWA-WEF, 1998). Adapun reaksi kimia yang terjadi pada penentuan amonia disajikan pada Gambar 2 (Park, 2009).

Berdasarkan reaksi tersebut dapat diketahui bahwa amonia air limbah bereaksi dengan natrium hipoklorit membentuk senyawa klor amin $\left(\mathrm{NH}_{2} \mathrm{Cl}\right)$ yang kemudian bereaksi dengan reagen fenolat membentuk senyawa antara monoklor kuinon. Selanjutnya, monoklor kuinon

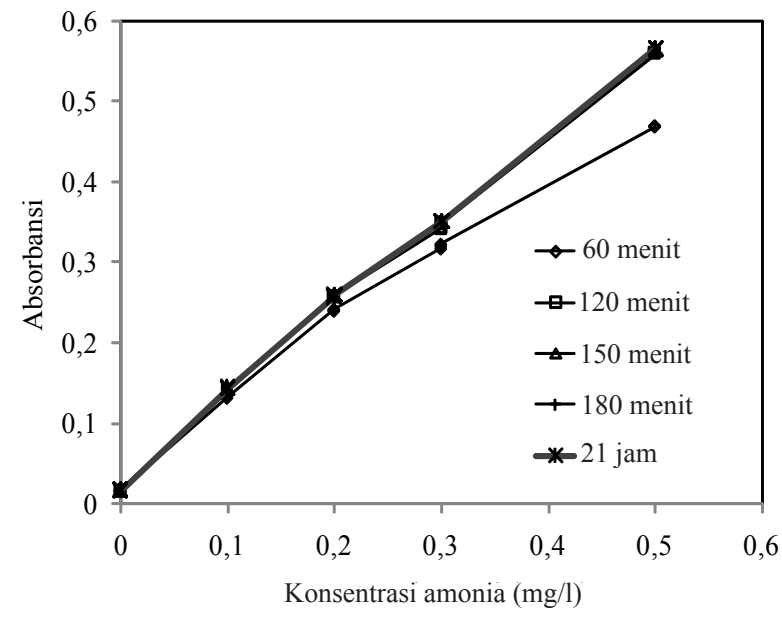

Gambar 1. Kurva standar fenat dengan variasi waktu reaksi pembentukan kompleks stabil 


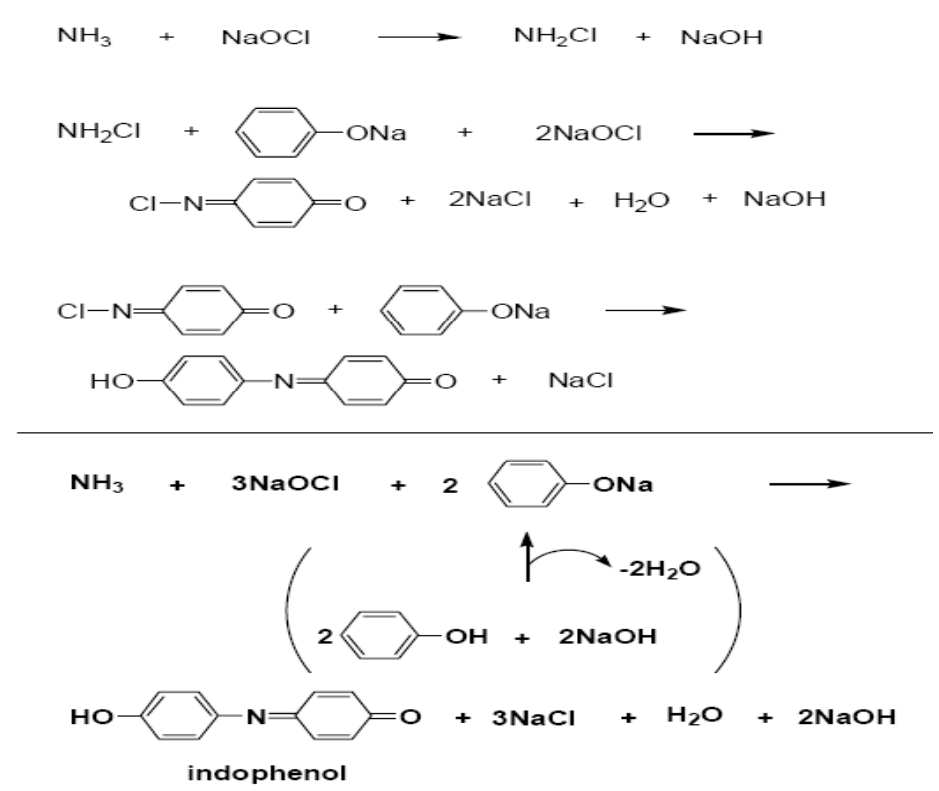

Gambar 2. Mekanisme reaksi kimia pembentukan kompleks indofenol dengan metode fenat

bereaksi dengan sisa reagen fenolat membentuk senyawa indophenol yang berwarna biru yang bisa dideteksi dengan spektrofotometer UVVIS. Pada reaksi pembentukan indofenol biru, natrium nitroprusside berfungsi sebagai katalis.

Waktu pembentukan kompleks stabil sangat dipengaruhi oleh suhu, pengujian percobaan ini dilakukan pada suhu $\pm 25^{\circ} \mathrm{C}$. Pengaruh suhu uji diterangkan oleh Duka and Cullaj (2010) bahwa pembuatan kurva standar $\mathrm{N}$-amonia dilakukan pada suhu $15^{\circ} \mathrm{C}$ mempunyai waktu stabilitas kompleks 72 jam dan kurva yang dihasilkannya pun tidak linier $(r=0,9897)$, sedangkan yang dilakukan pada suhu $40^{\circ} \mathrm{C}$ waktu optimum stabilitas kompleks dicapai dalam waktu 1 jam dan kurva yang dihasilkan sangat linier $(\mathrm{r}=0,9993)$. Kenaikan suhu membantu mempercepat pembentukan kompleks indofenol biru yang stabil bersama dengan katalis.

Hasil analisis menggunakan regresi linier dari pembuatan kurva standar disajikan dalam Tabel 1. Tabel 1 menunjukkan bahwa waktu optimum pembentukan kompleks stabil indofenol minimal 2 jam. Hal ini dapat dilihat dari nilai slope yang mulai konstan sampai waktu 21 jam dan juga nilai koefisien korelasi (r) telah memenuhi syarat yaitu $r>0,995$. Waktu optimum pembentukan kompleks stabil indofenol biru bisa berbeda-beda untuk tiap negara, hal ini sangat dipengaruhi oleh kondisi iklim di tiap negara. Di Korea, Korean Standard merekomendasikan waktu optimum pembentukan kompleks stabil indofenol biru selama 30 menit (Park, 2009).

\section{Penentuan Akurasi dan Presisi Metode}

Tahap yang sangat penting dalam pengembangan suatu metode uji adalah penentuan akurasi metode yaitu dengan menentukan persen recovery dengan melakukan spike matriks terhadap beberapa air limbah penyamakan kulit menggunakan larutan standar N-amonia. Adapun hasil penentuan persen recovery amonia

Tabel 1. Hasil analisis dengan regresi linear pada pembuatan kurva standar

\begin{tabular}{ccccc}
\hline Waktu (Jam) & Slope & Intersep & Koefisien korelasi (r) & Persaratan SNI \\
\hline 1 & 0,89 & 0,03 & 0,98 & $>0,995$ \\
2 & 1,07 & 0,02 & 0,99 & $>0,995$ \\
2,5 & 1,07 & 0,02 & 0,99 & $>0,995$ \\
3 & 1,08 & 0,02 & 0,99 & $>0,995$ \\
21 & 1,08 & 0,02 & 0,99 & $>0,995$ \\
\hline
\end{tabular}




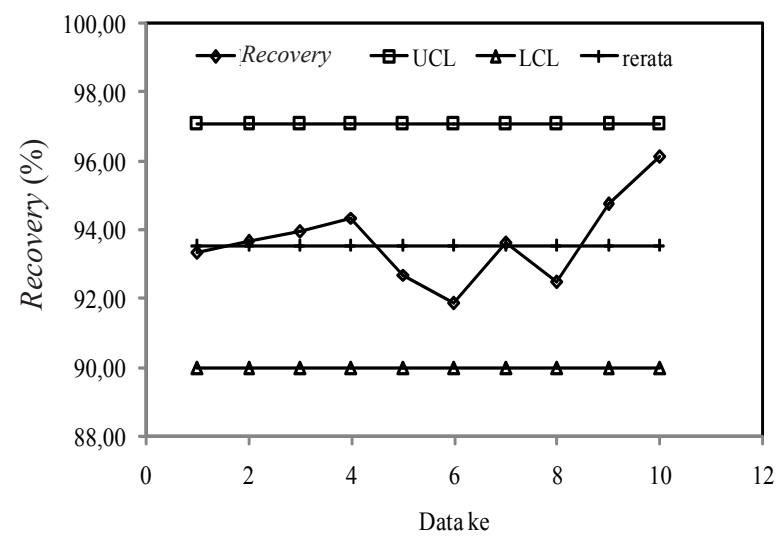

Gambar 3. Kurva akurasi uji N-amonia air limbah industri penyamakan kulit

seperti disajikan pada Gambar 3.

Gambar 3 menunjukkan hasil recovery uji amonia menghasilkan nilai upper control limit $97 \%$ dan lower control limit $90 \%$. Kedua nilai tersebut memenuhi kriteria keberterimaan SNI dengan persen recovery $85-115 \%$. Dengan demikian, pengembangan dan penggunaan metode fenat dinyatakan akurat.

Dalam uji presisi metode, Relative Percent Different (RPD) merupakan faktor yang dapat dikendalikan. RPD adalahi perbedaan dari pengukuran dua ulangan sampel. Hasil uji presisi metode disajikan pada Gambar 4.

Gambar 4 menunjukkan bahwa RPD hasil pengukuran berada dalam batas keberterimaan SNI yaitu $\mathrm{RPD}<5 \%$. Dengan demikian pengembangan metode uji amonia dengan waktu pembentukan kompleks minimal 2 jam mempunyai presisi yang baik, sehingga metode ini layak untuk digunakan sebagai acuan pengujian di laboratorium.

Banyak faktor yang dapat mempengaruhi nilai akurasi dan presisi uji. Kondisi reaksi merupakan hal terpenting yang harus diperhatikan. Dalam reaksi pembentukan kompleks stabil, masing-masing reagen berfungsi dalam capaian keberhasilan reaksi. Untuk uji $\mathrm{N}$-amonia, maka $\mathrm{pH}$ sangat menentukan dalam akurasi dan presisi uji. Hal ini disebabkan amonia di dalam air berada dalam dua bentuk yaitu berupa ion amonium $\left(\mathrm{NH}_{4}^{+}\right)$atau non-ion amonium $\left(\mathrm{NH}_{3}\right)$ (Handayani dan Widyastuti, 2009). Kondisi uji amonia adalah kondisi basa, untuk itu dalam pembuatan reagen uji diperlukan ketelitian tinggi agar kondisi kondusif reaksi dapat

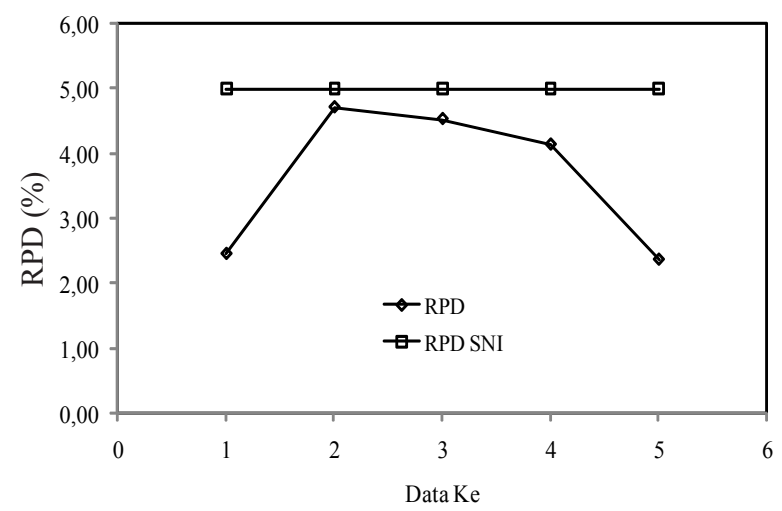

Gambar 4. Kurva presisi uji N-Amonia air limbah industri penyamakan kulit

dicapai. $\mathrm{pH}$ merupakan faktor penting dalam penentuan akurasi dan presisi dan nilai $\mathrm{pH}$ sangat dipengaruhi oleh suhu ruang. Untuk itu stabilitas suhu ruang perlu dijaga dengan menggunakan air conditioning (AC) dan dehumidifier.

\section{KESIMPULAN}

Optimasi waktu reaksi pembentukan kompleks stabil indofenol biru pada uji amonia air limbah industri penyamakan kulit dicapai pada waktu minimal 2 jam pada suhu uji $\pm 25^{\circ} \mathrm{C}$. Akurasi dan presisi memenuhi SNI-6989.302005 sehingga metode fenat layak untuk digunakan dan dikembangkan di laboratorium.

\section{UCAPAN TERIMA KASIH}

Tim peneliti mengucapkan terima kasih kepada Kepala Balai Besar Kulit, Karet dan Plastik atas pemberian izin penggunaan fasilitas peralatan laboratorium selama pelaksanaan penelitian.

\section{DAFTAR PUSTAKA}

Achmad, S., Rahayu, S., dan Sumarriani, Y., 2010. Penerapan grafik-x dan grafik-R sebagai grafik kendali dalam pengujian kualitas air. Jurnal Standardisasi. 12(1): 14-19.

APHA-AWWA-WEF, 1998. Standard methodfor the examination of water and wastewater, $20^{\text {th }}$ edition, American Public Health Association, Washington, USA.

Ashrafizadeh, S. N. and Khorasani, Z., 2010. Ammonia removal from aqueous solutions using hollow-fiber membrane contactors. 
Chemical Engineering Journal, 162(1): 242-249.

BSN (Badan Standardisasi Nasional), 2005. SNI6989.30-2005 Cara uji kadar $\mathrm{N}$-amonia dengan metode fenat.

Duka, S. and Cullaj, A., 2010. An optimal procedure for ammonia nitrogen analysis in natural water using indophenol blue method, Nature Montenegrina, 9(3): 743751.

Gubernur Kepala Daerah Istimewa Yogyakarta, 2010. Keputusan Gubernur Kepala Daerah Istimewa Yogyakarta nomor 7/KPTS/2010 tentang Baku Mutu Limbah Cair Bagi Kegiatan Industri di Propinsi Daerah Istimewa Yogyakarta

Handayani, N. dan Widyastuti, N., 2009. Adsorpsi ammonium $\left(\mathrm{NH}_{4}^{+}\right)$pada zeolit berkarbon dan zeolit A yang disintesis dari abu dasar batu bara PT. Ipmomi secara batch), Skripsi, Institut Teknologi Sepuluh Nopember

Jia, W. Y., Li, C. R., Qin, K., and Liu, L., 2010. Testing and analysis of drinking water quality in the rural areas of high-tech district in Tai'an City, Journal of Agricultural Science (1916-9752), 2(3): 155-157.

Li, Y., Li, W., Liu, B., Wang, K., Su, C., and $\mathrm{Wu}, \mathrm{C} ., 2$ 2013. Ammonia emissions and biodegradation of organic carbon during sewage sludge composting with different extra carbon sources. International Biodeterioration and Biodegradation, 85: 624-630.

Maas, A., Seibel, B. A., and Walsh, P. J., 2012. Effects of elevated ammonia concentrations on survival, metabolic rates, and glutamine synthetase activity in the Antarctic pteropod mollusk Clione limacina antarctica. Polar Biology, 35(7): 1123-1128.

Park, G. E., Oh, H. N., and Ahn, S., 2009. Improvement of the ammonia analysis by the phenate method in water and wastewater. Bulletin of the Korean Chemical Society, 30: 2032-2038.
Qingjun, Z., 2009. Research on key issues in determination of ammonia nitrogen in water and wastewater by Nessler's reagent spectrophotometry. Environmental Engineering, 1: 030.

Sattayatewa, C., Arnaldos, M., and Pagilla, K., 2011. Measurement of organic nitrogen and phosphorus fractions at very low concentrations in wastewater effluents. Water Environment Research, 83(8): 675683.

Sonthiphand, P. and Limpiyakorn, T., 2011. Change in ammonia-oxidizing microorganisms in enriched nitrifying activated sludge, Applied microbiology and Biotechnology, 89(3): 843-853.

Souza, N. K. P., Detmann, E., Valadares Filho, S. C., Costa, V. A. C., Pina, D. S., Gomes, D. I., and Mantovani, H. C., 2013. Accuracy of the estimates of ammonia concentration in rumen fluid using different analytical methods, Arquivo Brasileiro de Medicina Veterinária e Zootecnia, 65(6): 1752-1758.

Tzollas, N. M., Zachariadis, G. A., Anthemidis, A. N., and Stratis, J. A., 2010. A new approach to indophenol blue method for determination of ammonium in geothermal waters with high mineral content. International Journal of Environmental and Analytical Chemistry, 90(2): 115-126.

Wang, S., Wang, Y., Feng, X., Zhai, L., and Zhu, G., 2011. Quantitative analyses of ammonia-oxidizing Archaea and bacteria in the sediments of four nitrogen-rich wetlands in China, Applied microbiology and biotechnology, 90(2): 779-787.

Ya'nan, W., Xuepin, L., Qiang, H., and Bi, S., 2009. Comparison of distillation-titration method and nesslerization in determination of ammonia nitrogen in tannery wastewater, China Leather, 11: 003. 